\title{
Reactions of Ruthenium Acetylide Complexes with $\mathrm{EtO}_{2} \mathrm{CNCS:}$ Alkylation of the Thione with Dichloromethane
}

\author{
Chao-Wan Chang, ${ }^{\dagger}$ Ying-Chih Lin, ${ }^{*}, \ddagger$ Gene-Hsiang Lee, ${ }^{\ddagger}$ and Yu Wang ${ }^{\ddagger}$ \\ National University Preparatory School for Overseas Chinese Students, Linkou, \\ Taipei Hsien 244, Taiwan, Republic of China, and Department of Chemistry, \\ National Taiwan University, Taipei 106, Taiwan, Republic of China
}

Received May 8, 2003

\begin{abstract}
Treatment of the ruthenium acetylide complexes $[\mathrm{M}] \mathrm{C} \equiv \mathrm{CPh}\left(\mathbf{l a},[\mathrm{M}]=[\mathrm{Ru}]=\mathrm{Cp}\left(\mathrm{Ph}_{2^{-}}\right.\right.$ $\left.\mathrm{PCH}_{2} \mathrm{CH}_{2} \mathrm{PPh}_{2}\right) \mathrm{Ru}$; $\mathbf{l b}$, [M] $=\left[\mathrm{Ru}^{\prime}\right]=\mathrm{Cp}\left(\mathrm{PPh}_{3}\right)\left[\mathrm{P}(\mathrm{OMe})_{3}\right] \mathrm{Ru}$ ) with 1.1 equiv of $\mathrm{EtO}_{2} \mathrm{CN}=$ $\mathrm{C}=\mathrm{S}$ results in $[2+2]$ cycloadditions yielding the four-member ed-ring 2-iminothiete products $\mathbf{2} \mathbf{a}, \mathbf{b}$, respectively. Isomerization of complex $\mathbf{2} \mathbf{a}$ results in formation of $\mathbf{3} \mathbf{a}$ containing the six-membered-ring oxazinethione ligand. Alkylation of complex $3 a$ by $\mathrm{CH}_{2} \mathrm{Cl}_{2}$ takes place at the thione sulfur to give $\mathbf{4 a}$, which loses ethyl chloride, yiel ding the new six-membered-ring [1,3]-oxazin-2-one complex 5a. Further alkylation of $\mathbf{3 a}$ by the chloromethyl group of $\mathbf{5 a}$ affords the dinuclear complex $6 \mathbf{a}$ with two oxazin-2-one ligands bridged by a methylene group. Structures of $\mathbf{2} \mathbf{b}, \mathbf{3} \mathbf{a}, \mathbf{5} \mathbf{a}$ and $\mathbf{6} \mathbf{a}$ have been determined by single-crystal X-ray diffraction analysis.
\end{abstract}

\section{Introduction}

The synthesis and reactivity of metal acetylide complexes have been the focus of several recent works, due to their applications in organometallic ${ }^{1}$ and material ${ }^{2}$ chemistry. The coordinated acetylide ligand is reactive toward electrophiles, undergoing either alkylation or protonation at $\mathrm{C}_{\beta}$ to give stable vinylidene complexes. Cycloadditions of metal acetylide with isocyanates take place in several $\mathrm{Ni}(0)$ complexes. ${ }^{3}$ The other common reaction observed for the acetylide is the [2 + 2] cycloadditions of the triple bond with unsaturated organic substrates. ${ }^{4}$ Cycl oadditions of organic substrates such as $\mathrm{CS}_{2},{ }^{5}(\mathrm{NC})_{2} \mathrm{C}=\mathrm{C}\left(\mathrm{CF}_{3}\right)_{2},(\mathrm{NC})_{2} \mathrm{C}=\mathrm{C}(\mathrm{CN})_{2},{ }^{6}$ and $\mathrm{Ph}_{2} \mathrm{C}=\mathrm{C}=\mathrm{O}^{7}$ to the acetylide ligand in various metal complexes have been reported.

\footnotetext{
† National University Preparatory School for Overseas Chinese Students.

₹ National Taiwan University.

(1) (a) Beck, W.; Niemer, B.; Wieser, M. Angew. Chem., Int. Ed. Engl. 1993, 32, 923. (b) Hegedus, L. S. In Organometallics in Synthesis; Schlosser, M., Ed.; Wiley: New York, 1994; p 383. (c) Bartik, T.; Bartik, B.; Brady, M.; Dembinski, R.; Gladysz, J. A. Angew. Chem. 1996, 3S 414. (d) Ting, P. C.; Lin, Y. C.; Lee, G. H.; Cheng, M. C.; Wang, Y. J . Am. Chem. Soc. 1996, 118, 6433.

(2) (a) Myers, L. K.; Langhoff, C.; Thompson, M. B. J . Am. Chem. Soc. 1992, 114, 7560. (b) Kaharu, T.; Matsubara, H.; Takahashi, S. J Mater. Chem. 1992, 2, 43. (c) Lavastre, O.; Even, M.; Dixneuf, P. H.; Pacreau, A.; Vairon, J. P. Organometallics 1996, 15, 1530. (d) Wu, I. Y.; Lin, J . T.; Luo, J .; Sun, S. S.; Lee, C. S.; Lin, K. J .; Tsai, C.; Hsu, C. C.; Lin, J. L. Organometallics 1997, 16, 2038.

(3) Hoberg, H.; Oster, B. W. J . Organomet. Chem. 1983, 252, 359

(4) Bruce, M. I.; Hambley, T. W.; Leddell, M. J.; Snow, M. R.; Swincer, A. G.; Tiekink, R. T. Organometallics 1990, 9, 96.

(5) (a) Selegue, J. P. J. Am. Chem. Soc. 1982, 104, 119. (b) Birdwhistell, K. R.; Templeton, J . L. Organometallics 1985, 4, 2062. (c) Selegue, J. P.; Young, B. A.; Logan, S. L. Organometallics 1991 10, 1972.

(6) (a) Davison, A.; Solar, J . P. J . Organomet. Chem. 1979, 166, C13. (b) Bruce, M. I.; Hambley, T. W.; Snow, M. R.; Swincer, A. G. Organometallics 1985, 4, 501. (c) Barrette, A. G. M.; Carpenter, N. E. Mortier, J .; Sabat, M. Organometallics 1990, 9, 151.

(7) Hong, P.; Sonogashira, K.; Hagihara, N. J . Organomet. Chem.
} 1981, 219, 363.
In investigating chemical properties of acetylide complexes of ruthenium, we previously reported reactions of isocyanate and isothiocyanate with two such ruthenium complexes. ${ }^{8}$ The cycloaddition reaction of an isothiocyanate molecule with the ruthenium acetylide formed an unstable four-membered-ring 2-iminothiete complex. During purification, gradual loss of the isothiocyanate portion occurred in solution, giving back the acetylide complex. In the presence of excess isothiocyanates, expansion of the 2 -iminothiete rings by coupling of the second isothiocyanate molecule generated complexes with a six-membered-ring 2-imino-1,3-thiazine4-thione ligand. In this paper we report reactions of ruthenium acetylide complexes with $\mathrm{EtO}_{2} \mathrm{CNCS}$, a more reactive isothiocyanate. As expected, in the initial stage, cycloaddition of the $\mathrm{C}=\mathrm{S}$ bond of $\mathrm{EtO}_{2} \mathrm{CNCS}$ to the acetylide ligand gives the anticipated complex with the four-membered thiete ring containing an imino ester group. However, for the product with a dppe ligand, isomerization of this thiete ring generates a sixmembered oxazine ring with a thione group, at which alkylation by $\mathrm{CH}_{2} \mathrm{Cl}_{2}$ take place readily. Herein we report the synthesis and characterization of these thiete and oxazine complexes. An unusual alkylation of the thione group by using $\mathrm{CH}_{2} \mathrm{Cl}_{2}$ is also described.

\section{Results and Discussion}

Reactions of Ruthenium Acetylide Complexes with $\mathbf{E t O} \mathbf{C}_{2} \mathbf{C N C S}$. Treatment of $[\mathrm{Ru}] \mathrm{C} \equiv \mathrm{CPh}$ (la, $[\mathrm{Ru}]$ $=\mathrm{Cp}(\mathrm{dppe}) \mathrm{Ru}$ ) with 1.1 equiv of $\mathrm{EtO}_{2} \mathrm{CN}=\mathrm{C}=\mathrm{S}$ in $\mathrm{CHCl}_{3}$ at room temperature results in a color change of the solution from yellow to orange in $10 \mathrm{~min}$. The reaction is complete in $1 \mathrm{~h}$ and affords the orange

(8) Chang, C. W.; Lin, Y. C.; Lee, G. H.; Huang, S. L.; Wang, Y. Organometallics 1998, 17, 2534. 


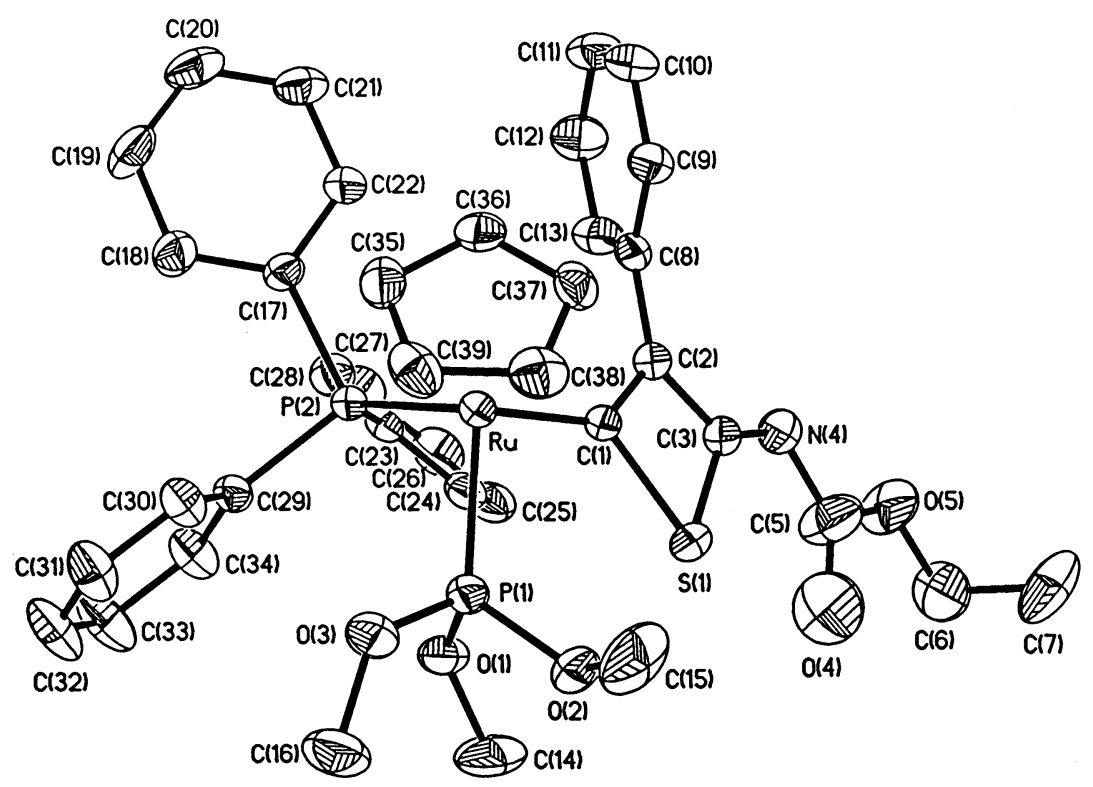

Figure 1. ORTEP drawing of $\mathbf{2 b}$. Thermal ellipsoids are drawn at the $50 \%$ probability level.

2-iminothiete product $[\mathrm{Ru}] \mathrm{C}=\mathrm{C}(\mathrm{Ph}) \mathrm{C}\left(=\mathrm{NCO}_{2} \mathrm{Et}\right) \mathrm{S}(\mathbf{2 a})$ in $92 \%$ isolated yield. We reported earlier ${ }^{8}$ that the optimized conditions for the reaction of $\mathbf{1 a}$ with PhNCS, yiel ding a similar product, required a 10-fold excess of PhNCS and a long reaction time (3 days). However, the reaction of $\mathbf{l a}$ with $\mathrm{EtO}_{2} \mathrm{CNCS}$ needs only a slight excess of isothiocyanate and is much faster. A [2+2] cycloaddition of the $\mathrm{C} \equiv \mathrm{C}$ triple bond of $\mathbf{1 a}$ to the $\mathrm{C}=\mathrm{S}$ double bond of $\mathrm{EtO}_{2} \mathrm{CNCS}$ satisfactorily accounts for the formation of $\mathbf{2 a}$. The ${ }^{31}$ P NMR spectrum of $\mathbf{2 a}$ displays a broad singl et resonance at $\delta 96.72$ assigned to the dppe ligand. The $F A B$ mass spectrum displays a parent peak at $m / z 798.2\left(M^{+}+1\right)$, consistent with the formula of 2a. Cycloaddition of a $\mathrm{C} \equiv \mathrm{C}$ bond of iron acetylide to $\mathrm{CS}_{2}$ was found to yield $2 \mathrm{H}$-thiete-2-thione ( $\beta$-dithiolactone). ${ }^{5}$ A similar process has been proposed in the first stage of the reaction of alkyne with $\mathrm{CS}_{2}$, giving a $2 \mathrm{H}$-thiete2-thione intermediate which was characterized spectroscopically. ${ }^{5}$ Reaction of phospheni um complexes with isocyanates via a $[2+2]$ addition of the $\mathrm{N}=\mathrm{C}$ bond to give the four-membered phosphametallacycles has also been reported. ${ }^{9}$

Similarly, treatment of the complex $\left[R u^{\prime}\right] \mathrm{C} \equiv \mathrm{CPh}$ ( $\mathbf{1 b}$, $\left.\left[\mathrm{Ru}^{\prime}\right]=\mathrm{Cp}\left(\mathrm{PPh}_{3}\right)\left[\mathrm{P}(\mathrm{OMe})_{3}\right] \mathrm{Ru}\right)$ with 1.1 equiv of $\mathrm{EtO}_{2^{-}}$ CNCS in $\mathrm{CH}_{2} \mathrm{Cl}_{2}$ at room temperature results in forma-

tion of the thiete product $\left[\mathrm{Ru}^{\prime}\right] \mathrm{C}=\mathrm{C}(\mathrm{Ph}) \mathrm{C}\left(=\mathrm{NCO}_{2} \mathrm{Et}\right) \mathrm{S}$ (2b) in $83 \%$ yield. In the ${ }^{31}$ P NMR spectrum, two doublet resonances at $\delta 152.72$ and 56.92 with $\mathrm{J}_{\mathrm{p}-\mathrm{p}}=67.1 \mathrm{~Hz}$ are assigned to the $\mathrm{P}(\mathrm{OMe})_{3}$ and $\mathrm{PPh}_{3}$ ligands, respectively. The parent peak in the $F A B$ mass spectrum is consistent with the formula. Complex $\mathbf{2} \mathbf{b}$ was recrystallized from a mixture of $\mathrm{CH}_{2} \mathrm{Cl}_{2}$ and hexane (1:3) at 5 ${ }^{\circ} \mathrm{C}$, and the molecular structure was determined by single-crystal X-ray diffraction analysis; an ORTEP drawing is shown in Figure 1. Crystal and intensity collection data are given in Table 1, and selected bond distances and angles are listed in Table 2. The coordination sphere of the ruthenium atom contains a $\eta^{5}$ cyclopentadienyl ring, two phosphorus atoms of phos-

(9) Malisch, W.; Hahner, C.; Grün, J .; Reising, J .; Goddard, R.; Krüger, C. Inorg. Chim. Acta 1996, 244, 147. phite and phosphine ligands, and the carbon atom (C1) of the organic ligand. The four-membered ring formed by $[2+2]$ cycloaddition is essentially planar, with a C1C2 distance of 1.373(7) $\AA$, typical of a C-C double bond. The bond distances for $\mathrm{C} 1-\mathrm{S} 1$ and C3-S1 (1.879(4) and $1.800(6) \AA$, respectively) are both typical of $\mathrm{C}-\mathrm{S}$ single bonds. 8,10 The $\mathrm{C} 3=\mathrm{N} 4$ bond distance of 1.277(6) $\AA$ confirms the presence of an imino group. The two ruthenium-phosphorus bonds in $\mathbf{2} \mathbf{b}$ are $\mathrm{Ru}-\mathrm{P} \mathbf{1}=$ 2.2312(13) $\AA$ and Ru-P2 = 2.3276(13) $\AA$, with the shorter distance bel onging to the phosphite ligand. The $\mathrm{S} 1-\mathrm{C} 1-\mathrm{C} 2, \mathrm{C} 1-\mathrm{C} 2-\mathrm{C} 3$, and $\mathrm{C} 2-\mathrm{C} 3-\mathrm{S} 1$ bond angles of $92.8(3), 100.8(4)$, and $94.1(4)^{\circ}$, respectively, are much smaller than an $\mathrm{sp}^{2}$ hybridization bond angle, and the $\mathrm{C} 1-\mathrm{S} 1-\mathrm{C} 3$ bond angle of $72.0(2)^{\circ}$ is smaller than a typical bond angle for a four-membered ring. Organic compounds containing similar four-membered rings with an imino group have been observed as stable products from the phosphine-induced elimination of a sulfur atom from some I,2-dithio-3-imi nes. ${ }^{11}$ The structural features of the 2-imino-2H-thiete portion, including the dihedral angle between the planes of the fourmembered ring and the phenyl substituent in the imino groups, are similar to those in $\mathbf{2 b}$.

Isomerization of $\mathbf{2 a}$. From the reaction of $\mathbf{1 a}$ with 1.1 equiv of $\mathrm{EtO}_{2} \mathrm{CNCS}$ for 1 day in $\mathrm{CHCl}_{3}$, a mixture containing $\mathbf{2 a}$ and $\mathbf{3 a}$ in a 1:3 ratio was isolated. Single crystals of $3 a$ suitable for X-ray diffraction analysis are obtained by recrystallization of the mixture from $\mathrm{CHCl}_{3} /$ n-pentane (1:3). Pure complex $\mathbf{2 a}$ in $\mathrm{CHCl}_{3}$ also undergoes isomerization to yiel $\mathbf{d}$ a mixture of $\mathbf{2 a}$ and $\mathbf{3 a}$ in a similar ratio. ${ }^{31}$ P NMR resonances of complexes $\mathbf{2} \mathbf{a}$ and 3a are al most identical (at $\delta 96.72$ and 96.03), but two ethyl groups are distinguishable in their ${ }^{1} \mathrm{H}$ NMR spectra. Resonances of the ethyl group of $\mathbf{3 a}$ appear at $\delta 3.79$ and 0.88 with $\mathrm{J} H-\mathrm{H}=7.05 \mathrm{~Hz}$. The $\mathrm{FAB}$ mass spectrum of $3 a$ displays a parent peak and fragmentation peaks comparable to that of $\mathbf{2 a}$. The structure of 3a has been determined by single crystal X-ray diffrac-

(10) Frank, G. W.; Degen, P. J . Acta Crystallogr., Sect. B 1973, B29, 1815

(11) Goerdeler, J .; Yunis, M.; Puff, H.; Roloff, A. Chem. Ber. 1986, 119, 162. 
Table 1. Crystal and Intensity Collection Data for Compounds $2 \mathrm{~b}, 3 \mathrm{a}, \mathbf{5 a}$, and $\mathbf{6 a}$

\begin{tabular}{|c|c|c|c|c|}
\hline & $2 \mathbf{b}$ & $3 a \cdot \mathrm{CHCl}_{3}{ }^{\mathrm{c}}$ & $5 \mathrm{a} \cdot \mathrm{CH}_{3} \mathrm{COCH}_{3}{ }^{\mathrm{C}}$ & $6 \mathrm{a} \cdot \mathrm{CH}_{3} \mathrm{OH}^{\mathrm{c}}$ \\
\hline $\begin{array}{l}\text { formula } \\
\text { fw }\end{array}$ & $\begin{array}{l}\mathrm{C}_{38} \mathrm{H}_{39} \mathrm{NO}_{5} \mathrm{P}_{2} \mathrm{RuS} \\
784.77\end{array}$ & $\begin{array}{l}\mathrm{C}_{44} \mathrm{H}_{40} \mathrm{Cl}_{3} \mathrm{NO}_{2} \mathrm{P}_{2} \mathrm{RuS} \\
916.19\end{array}$ & $\begin{array}{l}\mathrm{C}_{45} \mathrm{H}_{42} \mathrm{ClNO}_{3} \mathrm{P}_{2} \mathrm{RuS} \\
875.32\end{array}$ & $\begin{array}{l}\mathrm{C}_{84} \mathrm{H}_{74} \mathrm{~N}_{2} \mathrm{O}_{5} \mathrm{P}_{4} \mathrm{Ru}_{2} \mathrm{~S}_{2} \\
1581.59\end{array}$ \\
\hline temp, $\mathrm{K}$ & $295(2)$ & $150(1)$ & $295(2)$ & $295(2)$ \\
\hline cryst syst & triclinic & triclinic & monoclinic & triclinic \\
\hline space group & $\mathrm{P} \overline{1}$ & $\mathrm{P} \overline{1}$ & $\mathrm{P} 2_{1} / \mathrm{C}$ & $\mathrm{P} \overline{1}$ \\
\hline$a, \AA$ & $10.8554(2)$ & $14.1727(5)$ & $12.2203(1)$ & $14.82850(10)$ \\
\hline b, $\AA$ & $12.1181(2)$ & $15.6797(5)$ & $18.8528(2)$ & $16.0216(2)$ \\
\hline$c, \AA$ & $14.3910(1)$ & $18.5534(6)$ & $18.4824(1)$ & $16.63470(10)$ \\
\hline$\alpha$, deg & $88.109(1)$ & $94.6404(10)$ & 90 & $98.2560(10)$ \\
\hline$\beta$, deg & $79.027(1)$ & $98.1618(8)$ & $103.031(1)$ & $107.4950(10)$ \\
\hline$\gamma$, deg & $82.301(1)$ & $90.4884(8)$ & 90 & $91.1730(10)$ \\
\hline $\mathrm{V}, \AA^{3}$ & $1841.67(5)$ & $4067.0(2)$ & $4148.45(6)$ & $3721.65(6)$ \\
\hline Z & 2 & 4 & 4 & 2 \\
\hline $\mathrm{d}\left(\right.$ calcd), $\mathrm{Mg} / \mathrm{m}^{3}$ & 1.415 & 1.496 & 1.401 & 1.411 \\
\hline abs coeff, mm ${ }^{-1}$ & 0.612 & 0.752 & 0.610 & 0.602 \\
\hline$F(000)$ & 808 & 1872 & 1800 & 1624 \\
\hline no. of rflns collected & 20610 & 54419 & 28120 & 40442 \\
\hline no. of indep rflns & $7509\left(R_{\text {int }}=0.0611\right)$ & $18671\left(R_{\text {int }}=0.0614\right)$ & $8481\left(R_{\text {int }}=0.0315\right)$ & $13105\left(R_{\text {int }}=0.0634\right)$ \\
\hline $\mathrm{GOF}^{\mathrm{a}}$ on $\mathrm{F}^{2}$ & 1.028 & 1.113 & 1.088 & 1.014 \\
\hline $\mathrm{R}(I>2 \sigma(I))^{\mathrm{b}}$ & $\begin{array}{l}\mathrm{R} 1=0.0582 \\
w R 2=0.1229\end{array}$ & $\begin{array}{l}\mathrm{R} 1=0.0636 \\
w R 2=0.1294\end{array}$ & $\begin{array}{l}\mathrm{R} 1=0.0427 \\
w R 2=0.1141\end{array}$ & $\mathrm{R} 1=0.0406$ \\
\hline \multirow[t]{2}{*}{ R (all data) } & $\begin{array}{l}W R 2=0.1229 \\
R 1=0.0988\end{array}$ & $\begin{array}{l}\text { WR2 }=0.1294 \\
R 1=0.0859\end{array}$ & $\begin{array}{l}\text { WR2 }=0.1141 \\
\mathrm{R} 1=0.0535\end{array}$ & $\begin{array}{l}W R 2=0.0809 \\
R 1=0.0754\end{array}$ \\
\hline & $w R 2=0.1415$ & $w R 2=0.1404$ & $\mathrm{wR} 2=0.1221$ & $w R 2=0.0915$ \\
\hline peak, hole, e $\AA^{-3}$ & $1.056,-0.819$ & $0.945,-0.751$ & $1.066,-0.593$ & $0.591,-0.400$ \\
\hline
\end{tabular}

${ }^{a} \mathrm{GOF}=\left[\Sigma\left[w\left(F_{o}{ }^{2}-F_{c}{ }^{2}\right)^{2}\right] /(n-p)\right]^{1 / 2}$, where $n$ and $p$ denote the number of data and parameters. ${ }^{b} R 1=\left(\sum|| F_{0}|-| F_{c} \mid\right) / \Sigma\left|F_{0}\right|$ and wR2 $=\left[\Sigma\left[w\left(F_{o}^{2}-F_{c}^{2}\right)^{2}\right] / \Sigma\left[w\left(F_{o}^{2}\right)^{2}\right]\right]^{1 / 2}$ where $w=1 /\left[\sigma^{2}\left(F_{o}^{2}\right)+(a P)^{2}+b P\right]$ and $P=\left[F_{o}^{2}+2 F_{c}^{2}\right] / 3$. c The solvent was found to incorporate with the crystals.

Table 2. Selected Bond Distances $(\AA)$ and Angles (deg) of

$\mathrm{Cp}\left(\mathrm{PPh}_{3}\right)\left[\mathrm{P}(\mathrm{OMe})_{3}\right] \mathrm{RuC}=\mathrm{C}(\mathrm{Ph}) \mathrm{C}\left(=\mathrm{NCO}_{2} \mathrm{Et}\right) \mathrm{S}(2 \mathrm{~b})$

$\begin{array}{llll}\mathrm{Ru}-\mathrm{P}(1) & 2.2312(13) & \mathrm{Ru}-\mathrm{P}(2) & 2.3276(13) \\ \mathrm{Ru}-\mathrm{C}(1) & 2.012(5) & \mathrm{S}(1)-\mathrm{C}(1) & 1.879(4) \\ \mathrm{S}(1)-\mathrm{C}(3) & 1.800(6) & \mathrm{O}(4)-\mathrm{C}(5) & 1.271(9) \\ \mathrm{O}(5)-\mathrm{C}(5) & 1.158(10) & \mathrm{O}(5)-\mathrm{C}(6) & 1.463(8) \\ \mathrm{C}(1)-\mathrm{C}(2) & 1.373(7) & \mathrm{C}(2)-\mathrm{C}(3) & 1.433(6) \\ \mathrm{C}(3)-\mathrm{N}(4) & 1.277(6) & \mathrm{N}(4)-\mathrm{C}(5) & 1.407(8) \\ \mathrm{C}(6)-\mathrm{C}(7) & 1.473(9) & & \end{array}$

$\mathrm{P}(1)-\mathrm{Ru}-\mathrm{P}(2) \quad 92.37(5) \quad \mathrm{Ru}-\mathrm{C}(1)-\mathrm{C}(2) \quad 138.2(3)$

$\mathrm{C}(1)-\mathrm{Ru}-\mathrm{P}(1) \quad 90.17(13) \quad \mathrm{C}(3)-\mathrm{S}(1)-\mathrm{C}(1) \quad 72.0(2)$

$\mathrm{C}(5)-\mathrm{O}(5)-\mathrm{C}(6) \quad 122.0(10) \quad \mathrm{C}(2)-\mathrm{C}(1)-\mathrm{S}(1) \quad 92.8(3)$

$\mathrm{Ru}-\mathrm{C}(1)-\mathrm{S}(1) \quad 129.0(3) \quad \mathrm{C}(1)-\mathrm{C}(2)-\mathrm{C}(3) \quad 100.8(4)$

$\mathrm{C}(2)-\mathrm{C}(3)-\mathrm{S}(1) \quad 94.1(4) \quad \mathrm{C}(3)-\mathrm{N}(4)-\mathrm{C}(5) \quad 120.1(6)$

$\mathrm{O}(4)-\mathrm{C}(5)-\mathrm{O}(5) \quad 118.8(8) \quad \mathrm{O}(4)-\mathrm{C}(5)-\mathrm{N}(4) \quad 123.3(7)$

$\mathrm{O}(5)-\mathrm{C}(5)-\mathrm{N}(4) \quad 116.8(8)$

tion analysis. An ORTEP drawing is shown in Figure 2. Selected bond distances and angles are listed in Table 3. Two independent molecules, which are essentially very similar, are observed in the unit cell of the crystal, al ong with two solvated chloroform molecules. The sixmembered oxazinethione ring is basically planar, with a C1-C2 distance of 1.387(6) $\AA$, typical of a C $-\mathrm{C}$ double bond. The bond distance for C3-S1 (1.684(4) $\AA$ ) is typical of a $\mathrm{C}=\mathrm{S}$ double bond. The $\mathrm{C} 4=\mathrm{N} 1$ bond distance of 1.279(5) $\AA$ differs from the neighboring C3-N1 distance of $1.388(5) \AA$, indicating localization of double bonds in the six-membered ring.

The isomerization could involve opening of the fourmembered 2-iminothiete ring to form zwitterionic vinylidene with the anionic charge delocalized between the sulfur atom and the oxygen atom of the carbonyl group (see Scheme 1). A more el ectronegative oxygen atom makes 3a, with the six-membered oxazine ring containing a thione group, the predominant species after ring closure. Even though $\mathrm{EtO}_{2} \mathrm{CNCS}$ is known to undergo nucleophilic attack at the isothiocyanate $\mathrm{C}$ atom, ${ }^{12}$ the fact that no $3 a$ is observed in the early stage of the reaction of $\mathbf{l a}$ with $\mathrm{EtO}_{2} \mathrm{CNCS}$ indicates that

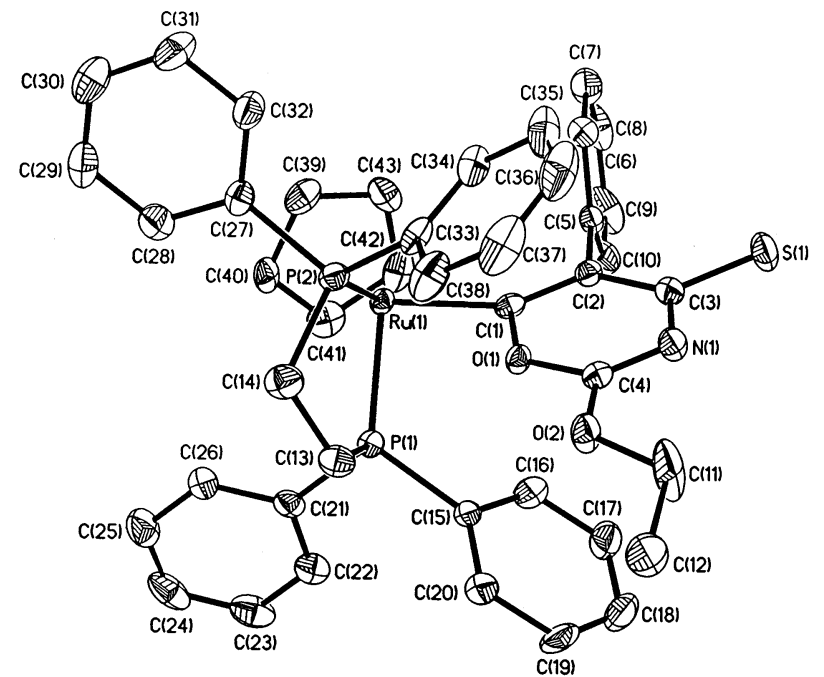

Figure 2. ORTEP drawing of $3 a \cdot \mathrm{CHCl}_{3}$. Thermal ellipsoids are drawn at the $50 \%$ probability level. Chloroform molecules are omitted for clarity.

formation of $\mathbf{2 a}$ may involve a fast concerted [2 +2$]$ cycl oaddition, not via the zwitterionic vinylidene intermediate. Transformation between $\mathbf{2 a}$ and $\mathbf{3 a}$ is a slow step. It takes 1 day to establish the equilibrium of $\mathbf{2 a}$ and $3 a$ in a 1:3 ratio.

Alkylation Reaction at the Thione Sulfur of the Oxazine Complex. The reaction of complex $2 a$ with $\mathrm{CH}_{2} \mathrm{Cl}_{2}$ for 4 days gave the six-membered oxazine complex $[\mathrm{Ru}] \mathrm{C}=\mathrm{C}(\mathrm{Ph}) \mathrm{C}\left(\mathrm{SCH}_{2} \mathrm{Cl}\right) \mathrm{NC}(=\mathrm{O}) \mathrm{O}(\mathbf{5 a})$ in $87 \%$ isolated yield. The reaction of $3 a$ with $\mathrm{CH}_{2} \mathrm{Cl}_{2}$ takes 3 days to give $\mathbf{5 a}$ in high yield. Also direct reaction of $\mathbf{1 a}$ with a 5-fold excess of $\mathrm{EtO}_{2} \mathrm{CNCS}$ in $\mathrm{CH}_{2} \mathrm{Cl}_{2}$ at room

(12) (a) Kurzer, F.; Secker, J . L. J . Heterocycl. Chem. 1989, 26, 355. (b) Molina, P.; Alajarin, M.; Lopez-Lazaro, A. Tetrahedron 1991, 47, 6747. (c) Molina, P.; Alajarin, M.; Arques, A.; Benzal, R.J . Chem. Soc., Perkin Trans. 1 1982, 351. (d) Garmaise, D. L.; Schwartz, R.; Mckay, A. F. J . Am. Chem. Soc. 1958, 80, 3332. 
Table 3. Selected Bond Distances $(\AA)$ and Angles (deg) of $\mathbf{C p}$ (dppe)R uC $=\mathbf{C}(\mathrm{Ph}) \mathrm{C}(=\mathrm{S}) \mathrm{N}=\mathrm{C}(\mathrm{OEt}) \mathbf{O}$ (3a)

\begin{tabular}{llll}
\hline $\mathrm{Ru}(1)-\mathrm{P}(1)$ & $2.2756(11)$ & $\mathrm{Ru}(1)-\mathrm{C}(1)$ & $2.047(4)$ \\
$\mathrm{Ru}(1)-\mathrm{P}(2)$ & $2.2619(12)$ & $\mathrm{S}(1)-\mathrm{C}(3)$ & $1.684(4)$ \\
$\mathrm{O}(1)-\mathrm{C}(1)$ & $1.420(5)$ & $\mathrm{O}(1)-\mathrm{C}(4)$ & $1.323(5)$ \\
$\mathrm{O}(2)-\mathrm{C}(4)$ & $1.323(5)$ & $\mathrm{O}(2)-\mathrm{C}(11)$ & $1.443(6)$ \\
$\mathrm{N}(1)-\mathrm{C}(4)$ & $1.279(5)$ & $\mathrm{N}(1)-\mathrm{C}(3)$ & $1.388(5)$ \\
$\mathrm{C}(1)-\mathrm{C}(2)$ & $1.387(6)$ & $\mathrm{C}(2)-\mathrm{C}(3)$ & $1.436(6)$ \\
$\mathrm{C}(1)-\mathrm{Ru}(1)-\mathrm{P}(1)$ & $87.69(12)$ & $\mathrm{C}(1)-\mathrm{Ru}(1)-\mathrm{P}(2)$ & $89.36(12)$ \\
$\mathrm{P}(1)-\mathrm{Ru}(1)-\mathrm{P}(2)$ & $84.59(4)$ & $\mathrm{C}(4)-\mathrm{O}(1)-\mathrm{C}(1)$ & $122.1(3)$ \\
$\mathrm{C}(4)-\mathrm{O}(2)-\mathrm{C}(11)$ & $116.3(4)$ & $\mathrm{C}(4)-\mathrm{N}(1)-\mathrm{C}(3)$ & $115.8(4)$ \\
$\mathrm{C}(2)-\mathrm{C}(1)-\mathrm{Ru}(1)$ & $136.5(3)$ & $\mathrm{C}(2)-\mathrm{C}(1)-\mathrm{O}(1)$ & $112.9(3)$ \\
$\mathrm{O}(1)-\mathrm{C}(1)-\mathrm{Ru}(1)$ & $110.6(3)$ & $\mathrm{C}(1)-\mathrm{C}(2)-\mathrm{C}(3)$ & $121.7(4)$ \\
$\mathrm{N}(1)-\mathrm{C}(3)-\mathrm{C}(2)$ & $120.1(4)$ & $\mathrm{N}(1)-\mathrm{C}(3)-\mathrm{S}(1)$ & $116.5(3)$ \\
$\mathrm{C}(2)-\mathrm{C}(3)-\mathrm{S}(1)$ & $123.4(3)$ & $\mathrm{N}(1)-\mathrm{C}(4)-\mathrm{O}(1)$ & $127.4(4)$ \\
$\mathrm{N}(1)-\mathrm{C}(4)-\mathrm{O}(2)$ & $124.7(4)$ & $\mathrm{O}(1)-\mathrm{C}(4)-\mathrm{O}(2)$ & $107.9(4)$
\end{tabular}

temperature for 7 days afforded $\mathbf{5 a}$ with lower overall yield. The reaction carried out in $\mathrm{CHCl}_{3}$ yielded no alkylation product. Characterization of $\mathbf{5 a}$ by spectroscopic methods and by structure determination indicates that an unusual alkylation by $\mathrm{CH}_{2} \mathrm{Cl}_{2}$ takes place at the thione sulfur atom. Resonances at $\delta 4.86$ and 43.1 in the ${ }^{1} \mathrm{H}$ and ${ }^{13} \mathrm{C}$ NMR spectra, respectively, of $\mathbf{5 a}$ are assigned to the chloromethyl group on the sulfur atom. The reaction also yielded volatile ethyl chloride, observed by the ${ }^{1} \mathrm{H}$ NMR spectrum of the reaction mixture. Complex 5a was recrystallized from a mixture of acetone and hexane $(1: 3)$ at $5{ }^{\circ} \mathrm{C}$, and the molecular structure was determined by single-crystal X-ray diffraction analysis; an ORTEP drawing of $\mathbf{5 a}$ is shown in Figure 3 , and selected bond distances and angles are listed in Table 4. The bond distance of Ru-C(1) (2.040(3) $\AA$ ) is typical of a $\mathrm{Ru}-\mathrm{C}$ single bond. The $\mathrm{C}(1)-\mathrm{C}(2), \mathrm{N}(1)-$ $C(9)$, and $N(1)-C(10)$ bond lengths of 1.399(4), 1.355(5), and 1.324(4) $\AA$, respectively, all displaying partial double-bond character, are indicative of several resonance contributions. The bond distance of $\mathrm{O}(2)-\mathrm{C}(9)$ is 1.214(4) $\AA$, comparable to an idealized $C=0$ double bond. The bond distances of $\mathrm{O}(1)-\mathrm{C}(9)(1.385(4) \AA)$ and
Scheme 1
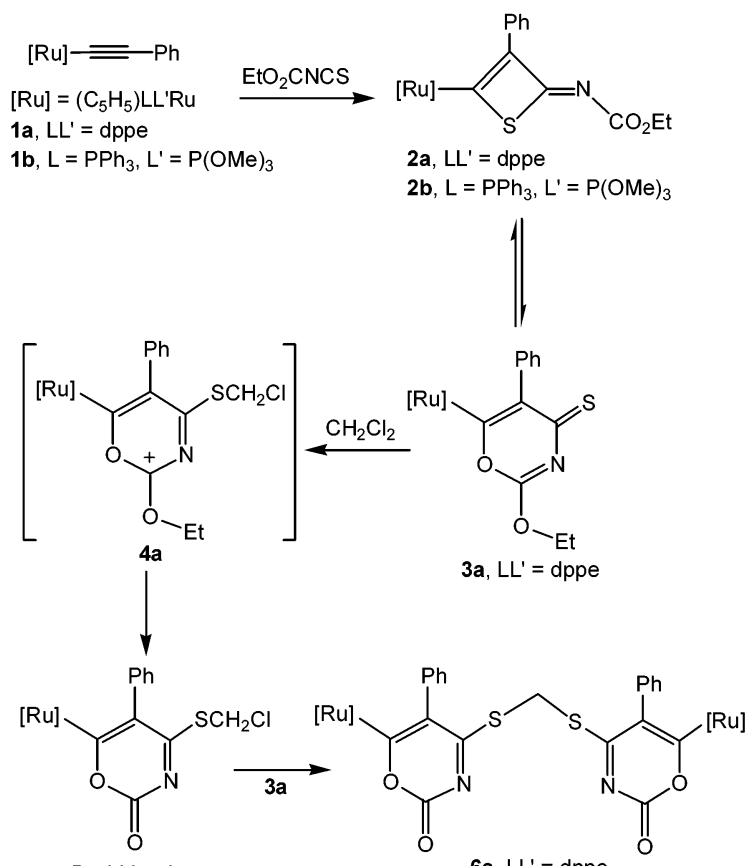

5a, $L^{\prime}=$ dppe

6a, $L L^{\prime}=$ dppe

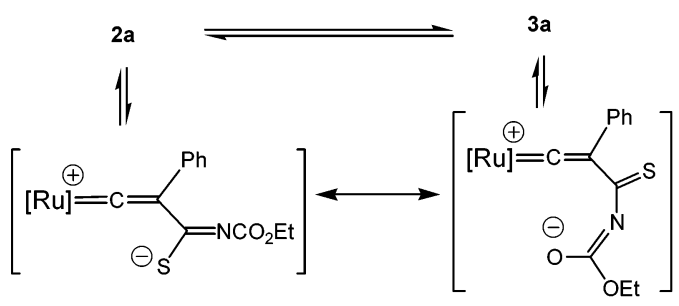

$\mathrm{O}(1)-\mathrm{C}(1)(1.398(4) \AA)$ are both typical of a $\mathrm{C}-\mathrm{O}$ single bond. The heterocyclic six-membered oxazine ring is essentially planar. The bond angle $\mathrm{S}(1)-\mathrm{C}(11)-\mathrm{Cl}(1)$ of the thiochloromethyl group is $114.4(3)^{\circ}$, close to that expected for $\mathrm{C}\left(\mathrm{sp}^{3}\right)$ hybridization. The bond distances

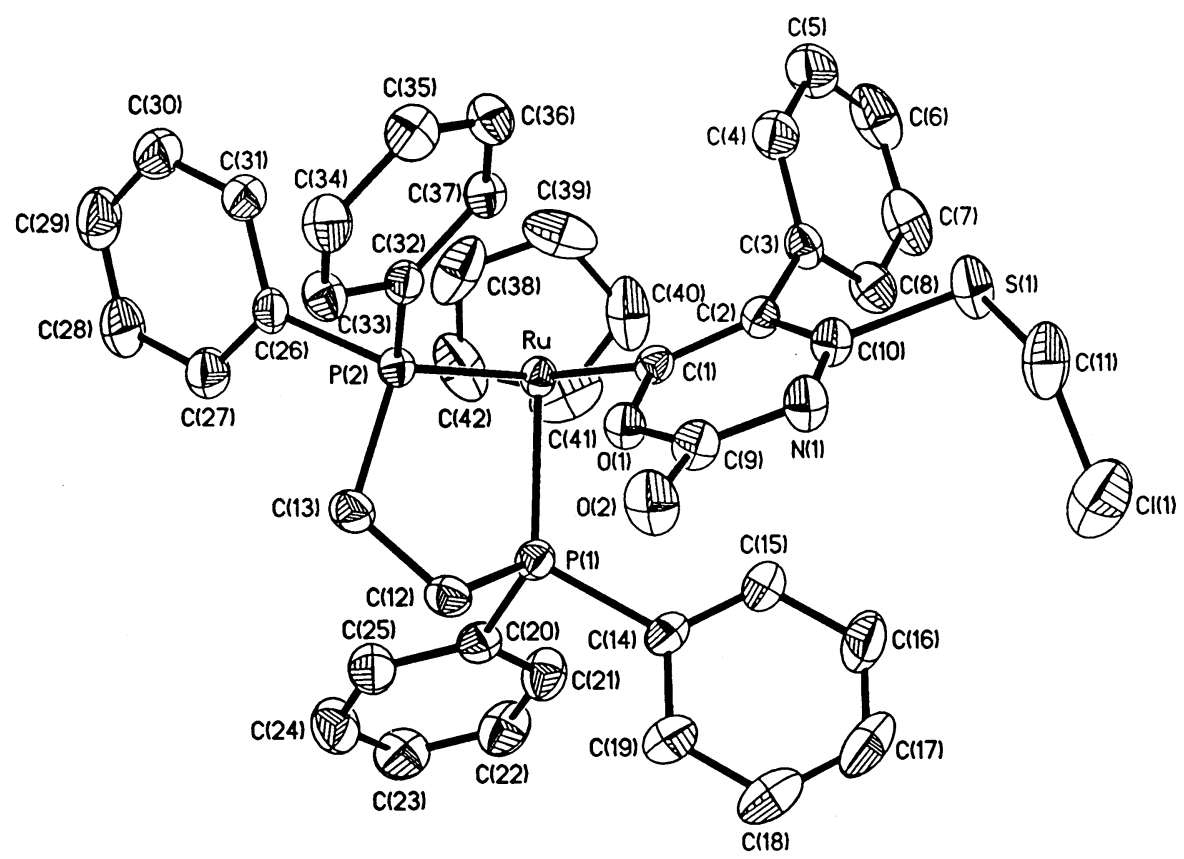

Figure 3. ORTEP drawing of $\mathbf{5 a} \cdot \mathrm{CH}_{3} \mathrm{COCH}_{3}$. Thermal ellipsoids are drawn at the $50 \%$ probability level. Acetone molecules are omitted for clarity. 


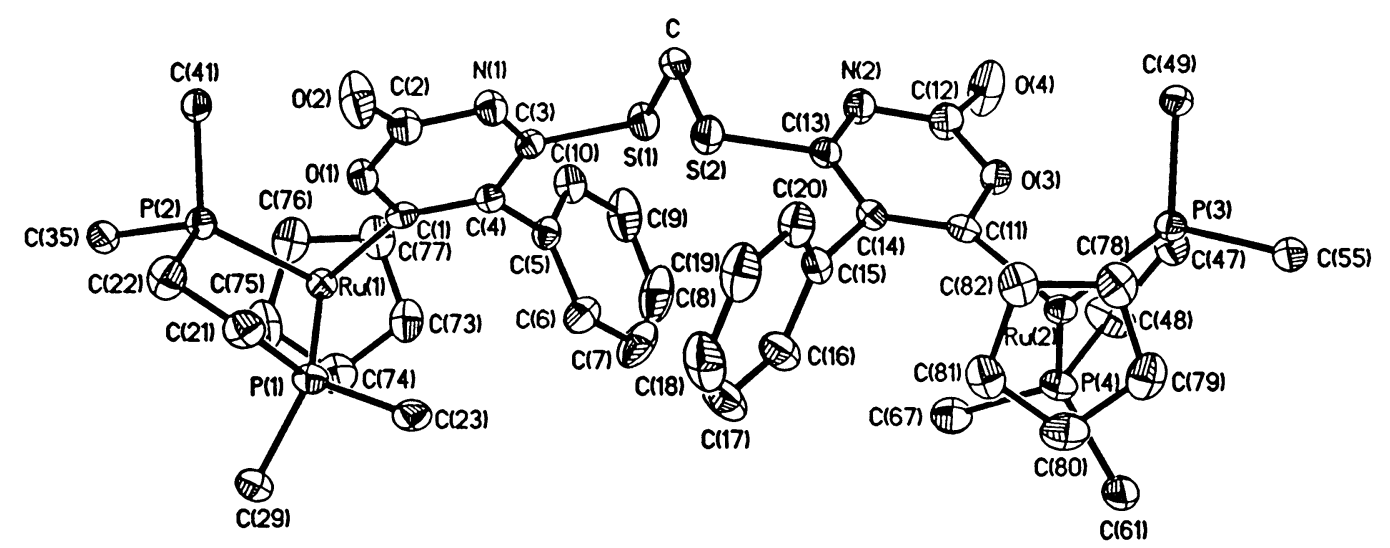

Figure 4. ORTEP drawing of $\mathbf{6 a} \cdot \mathrm{CH}_{3} \mathrm{OH}$. Thermal ellipsoids are drawn at the $50 \%$ probability level. Methanol molecules are omitted for clarity. For the phenyl groups on dppe, only the ipso carbons are shown.

Table 4. Selected Bond Distances $(\AA)$ and Angles (deg) of $\mathrm{Cp}$ (dppe)R $\mathrm{RC}=\mathrm{C}(\mathrm{Ph}) \mathrm{C}\left(\mathrm{SCH}_{2} \mathrm{Cl}\right) \mathrm{NC}(=0) \mathrm{O}$ (5a)

\begin{tabular}{lllr}
\hline $\mathrm{Ru}-\mathrm{P}(1)$ & $2.2694(9)$ & $\mathrm{Ru}-\mathrm{C}(1)$ & $2.040(3)$ \\
$\mathrm{Ru}-\mathrm{P}(2)$ & $2.2774(87)$ & $\mathrm{S}(1)-\mathrm{C}(10)$ & $1.783(4)$ \\
$\mathrm{S}(1)-\mathrm{C}(11)$ & $1.781(5)$ & $\mathrm{Cl}(1)-\mathrm{C}(11)$ & $1.764(6)$ \\
$\mathrm{O}(1)-\mathrm{C}(9)$ & $1.385(4)$ & $\mathrm{O}(2)-\mathrm{C}(9)$ & $1.214(4)$ \\
$\mathrm{O}(1)-\mathrm{C}(1)$ & $1.398(4)$ & $\mathrm{N}(1)-\mathrm{C}(9)$ & $1.355(5)$ \\
$\mathrm{N}(1)-\mathrm{C}(10)$ & $1.324(4)$ & $\mathrm{C}(1)-\mathrm{C}(2)$ & $1.399(4)$ \\
$\mathrm{C}(2)-\mathrm{C}(10)$ & $1.408(5)$ & & \\
$\mathrm{C}(1)-\mathrm{Ru}-\mathrm{P}(1)$ & $86.20(9)$ & $\mathrm{C}(1)-\mathrm{Ru}-\mathrm{P}(2)$ & $90.45(9)$ \\
$\mathrm{P}(1)-\mathrm{Ru}-\mathrm{P}(2)$ & $84.24(3)$ & $\mathrm{C}(9)-\mathrm{O}(1)-\mathrm{C}(1)$ & $126.2(3)$ \\
$\mathrm{C}(10)-\mathrm{N}(1)-\mathrm{C}(9)$ & $116.1(3)$ & $\mathrm{C}(2)-\mathrm{C}(1)-\mathrm{O}(1)$ & $113.0(3)$ \\
$\mathrm{C}(2)-\mathrm{C}(1)-\mathrm{Ru}$ & $133.9(2)$ & $\mathrm{O}(1)-\mathrm{C}(1)-\mathrm{Ru}$ & $112.9(2)$ \\
$\mathrm{C}(1)-\mathrm{C}(2)-\mathrm{C}(10)$ & $118.1(3)$ & $\mathrm{C}(1)-\mathrm{C}(2)-\mathrm{C}(3)$ & $123.1(3)$ \\
$\mathrm{C}(10)-\mathrm{C}(2)-\mathrm{C}(3)$ & $118.8(3)$ & $\mathrm{O}(2)-\mathrm{C}(9)-\mathrm{O}(1)$ & $115.6(3)$ \\
$\mathrm{O}(2)-\mathrm{C}(9)-\mathrm{N}(1)$ & $125.2(3)$ & $\mathrm{N}(1)-\mathrm{C}(9)-\mathrm{O}(1)$ & $119.1(3)$ \\
$\mathrm{N}(1)-\mathrm{C}(10)-\mathrm{C}(2)$ & $127.1(3)$ & $\mathrm{N}(1)-\mathrm{C}(10)-\mathrm{S}(1)$ & $116.8(3)$ \\
$\mathrm{C}(2)-\mathrm{C}(10)-\mathrm{S}(1)$ & $116.2(2)$ & $\mathrm{Cl}(1)-\mathrm{C}(11)-\mathrm{S}(1)$ & $114.4(3)$
\end{tabular}

$\mathrm{S}(1)-\mathrm{C}(11)$ and $\mathrm{C}(11)-\mathrm{Cl}(1)$ of $1.781(5)$ and 1.764(6) $\AA$, respectively, are in the range of normal $\mathrm{C}-\mathrm{S}$ and $\mathrm{C}-\mathrm{Cl}$ single bonds.

Alkylation of the six-membered thiazine thione ring is known ${ }^{13}$ to take place at the thione sulfur atom. It is therefore not surprising to see the formation of $\mathbf{5 a}$ from $\mathbf{3 a}$ or from $\mathbf{2} \mathbf{a}$ in $\mathrm{CH}_{2} \mathrm{Cl}_{2}$. F ormation of $\mathbf{5 a}$ from $\mathbf{2 a}$ could be induced ${ }^{14}$ initially by isomerization of $\mathbf{2 a}$ to $\mathbf{3 a}$ followed by nucleophilic attack of the thione sulfur at $\mathrm{CH}_{2} \mathrm{Cl}_{2}$ (Scheme 1). This unusual alkylation at the sulfur atom stimulates us to investigate this reaction in detail. The reaction of $\mathbf{2 a}$ with $\mathrm{CH}_{2} \mathrm{Cl}_{2}$ reveals some interesting insight into the process. When the reaction is monitored by ${ }^{31} \mathrm{P}$ NMR spectroscopy, an additional intermediate is observed. Within 1 day, the ${ }^{31} \mathrm{P}$ resonance at $\delta 96.72$ of $\mathbf{2 a}$ diminished while a resonance at $\delta 96.03$ attributed to 3a appeared. This was followed by the emergence of a new resonance at $\delta 92.7$ assignable to the intermediate $\mathbf{4 a}$. After two more days, the ${ }^{31} \mathrm{p}$ resonance attributed to the final product $\mathbf{5 a}$ ap-

(13) (a) Chang, C. W.; Lin, Y. C.; Lee, G. H.; Huang, S. L.; Wang, Y. J. Organomet. Chem. 2002, 660, 127. (b) Schatz, J ; Sauer, J. Tetrahedron Lett. 1994, 35, 4767. (c) Kakioka, Y.; Uebori, S.; Tsuno, M.; Taniguchi, Y.; Takaki, K.; Fujiwara, Y. J . Org. Chem. 1996, 61 , 372.

(14) (a) Mukerjee, A. K.; Ashare, R. Chem. Rev. 1991, 91, 1. (b) Adams, R. D.; Huang, M. Chem. Ber. 1996, 129, 485. (c) Adams, R. D.; Chen, L.; Wu, W. Organometallics 1993, 12, 3812. (d) Adams, R. D.; Huang, M. Organometallics 1996, 15, 2125. (e) Cowie, M.; Dwight, S. K. J . Organomet. Chem. 1980, 198, C20. (f) Werner, H. Coord. Chem. Rev. 1982, 43, 165. peared at $\delta$ 98.65. The intermediate $\mathbf{4 a}$ could possibly be a cationic alkylation product before loss of EtCl (see Scheme 1). Formation of $\mathbf{5 a}$ is thus considered to proceed via a stepwise process.

Formation of $\mathbf{5 a}$ from $\mathbf{2 a}$ is concentration dependent; namely, $5 \mathbf{a}$ is the only product $(87 \%$ yield) at the concentration of $5 \mathrm{mM}$ of $\mathbf{2 a}$ in $\mathrm{CH}_{2} \mathrm{Cl}_{2}$, but at higher concentration ( $25 \mathrm{mM}$ ), in addition to 5 a (ca. $50 \%$ yield), the new product $[\mathrm{Ru}] \mathrm{C}=\mathrm{C}(\mathrm{Ph}) \mathrm{C}(\mathrm{S}-) \mathrm{NC}(=\mathrm{O}) \mathrm{O}_{2} \mathrm{CH}_{2}(\mathbf{6 a})$ formed in $33 \%$ yield. Complex $\mathbf{6 a}$, insoluble in acetone, is readily separated from $\mathbf{5 a}$ by washing the mixture with acetone. The NMR spectra of complexes $5 \mathbf{a}$ and $\mathbf{6} \mathbf{a}$ are very similar. The FAB mass spectrum of $\mathbf{6 a}$ displays a parent peak at $\mathrm{m} / \mathrm{z}$ 1551.0. Complex $\mathbf{6 a}$ is a stable yellow compound, soluble in polar solvents such as $\mathrm{CH}_{2} \mathrm{Cl}_{2}$ and $\mathrm{CHCl}_{3}$, moderately soluble in acetone, acetonitrile, and methanol, and insoluble in diethyl ether and hexane. Formation of $\mathbf{6 a}$ could occur by a nucleophilic attack of the thione sulfur atom of $\mathbf{3 a}$ at the chloromethyl group of $\mathbf{5 a}$, followed by elimination of EtCl. Recently Grapperhaus et al . reported a similar reaction that $\mathrm{CH}_{2} \mathrm{Cl}_{2}$ alkylated a trithiolato-ruthenium complex to yield a methylene-bridged thioether core. ${ }^{15}$

Recrystallization of $\mathbf{6 a}$ by slow evaporation of a $\mathrm{CH}_{2-}$ $\mathrm{Cl}_{2} / \mathrm{MeOH}$ sol ution at room temperature affords yellow crystals. The structure of $\mathbf{6 a}$ has been determined by single-crystal X-ray diffraction analysis. An ORTEP drawing is shown in Figure 4, and selected bond distances and angles are listed in Table 5. The bond distances of both $\mathrm{Ru}(1)-\mathrm{C}(1)$ (2.041(3) $\AA$ ) and $\mathrm{Ru}(2)-$ $\mathrm{C}(11)(2.041(3) \AA)$ are typical of a Ru-C single bond. The $C(1)-C(4)$ and $C(11)-C(14)$ bond lengths of 1.396(4) and 1.395(4) $\AA$ indicate double bonds. The C(3)-N(1), $\mathrm{C}(13)-\mathrm{N}(2), \mathrm{C}(2)-\mathrm{N}(1)$, and $\mathrm{C}(12)-\mathrm{N}(2)$ bond lengths of $1.330(4), 1.328(4), 1.343(4)$, and $1.357(4) \AA$, respectively, all display partial double-bond character. The bond distance of $\mathrm{C}(2)-\mathrm{O}(2)$ is $1.221(4) \AA$, comparable to an ideal ized $\mathrm{C}-\mathrm{O}$ double bond. Both heterocyclic sixmembered-ring ligands are essentially coplanar. The methylene-bridged bond angle S(2)-C-S(1) (114.77$\left.(18)^{\circ}\right)$ is close to $\mathrm{S}(2)-\mathrm{C}(11)-\mathrm{Cl}(1)$ in $5 \mathbf{a}$. The bond distances of $\mathrm{S}(1)-\mathrm{C}$ and $\mathrm{S}(2)-\mathrm{C}$ (1.799(3) and 1.795(3) $\AA$, respectively) are in the range of a normal $\mathrm{C}-\mathrm{S}$ single bond. Ligand-based reactivity of metal-coordinated thiolates has been known in the literature, and alkylation,

(15) (a) Grapperhaus, C. A.; Poturovic, S.; Mashuta, M. S. Inorg. Chem. 2002, 41, 4309. 
Table 5. Selected Bond Distances ( $(\AA)$ and Angles (deg) of [Cp(dppe)R uC $=\mathrm{C}(\mathrm{Ph}) \mathrm{C}(\mathrm{S}-) \mathrm{N}(=\mathrm{O}) \mathrm{O}]_{2} \mathrm{CH}_{2}$ (6a)

$\begin{array}{llll}\mathrm{Ru}(1)-\mathrm{C}(1) & 2.041(3) & \mathrm{Ru}(2)-\mathrm{C}(11) & 2.041(3) \\ \mathrm{O}(1)-\mathrm{C}(2) & 1.391(4) & \mathrm{O}(2)-\mathrm{C}(2) & 1.221(4) \\ \mathrm{O}(1)-\mathrm{C}(1) & 1.404(4) & \mathrm{O}(3)-\mathrm{C}(12) & 1.395(4) \\ \mathrm{O}(3)-\mathrm{C}(11) & 1.399(4) & \mathrm{O}(4)-\mathrm{C}(12) & 1.208(4) \\ \mathrm{C}(1)-\mathrm{C}(4) & 1.396(4) & \mathrm{C}(11)-\mathrm{C}(14) & 1.395(4) \\ \mathrm{C}(3)-\mathrm{C}(4) & 1.420(4) & \mathrm{C}(13)-\mathrm{C}(14) & 1.417(4) \\ \mathrm{N}(1)-\mathrm{C}(3) & 1.330(4) & \mathrm{N}(2)-\mathrm{C}(13) & 1.328(4) \\ \mathrm{N}(1)-\mathrm{C}(2) & 1.343(4) & \mathrm{N}(2)-\mathrm{C}(12) & 1.357(4) \\ \mathrm{S}(1)-\mathrm{C}(3) & 1.773(3) & \mathrm{S}(2)-\mathrm{C}(13) & 1.774(3) \\ \mathrm{S}(1)-\mathrm{C} & 1.799(3) & \mathrm{S}(2)-\mathrm{C} & 1.795(3) \\ \mathrm{C}(2)-\mathrm{O}(1)-\mathrm{C}(1) & 125.5(3) & \mathrm{O}(1)-\mathrm{C}(1)-\mathrm{Ru}(1) & 114.4(2) \\ \mathrm{C}(2)-\mathrm{N}(1)-\mathrm{C}(3) & 116.5(3) & \mathrm{S}(2)-\mathrm{C}-\mathrm{S}(1) & 114.77(18) \\ \mathrm{N}(1)-\mathrm{C}(2)-\mathrm{O}(1) & 119.8(3) & \mathrm{N}(1)-\mathrm{C}(3)-\mathrm{S}(1) & 117.7(2) \\ \mathrm{C}(1)-\mathrm{C}(4)-\mathrm{C}(3) & 118.4(3) & \mathrm{N}(1)-\mathrm{C}(3)-\mathrm{C}(4) & 126.3(3) \\ \mathrm{C}(3)-\mathrm{S}(1)-\mathrm{C} & 101.94(16) & \mathrm{C}(4)-\mathrm{C}(3)-\mathrm{S}(1) & 116.0(2) \\ & & & \end{array}$

metalation, oxygenation, and adduct formation have all been recognized. ${ }^{16}$ The strength of the coordinated thiolate's nucleophilicity was established by the fact that even weak electrophiles, such as $\mathrm{CH}_{2} \mathrm{Cl}_{2}$, are prone to attack. In the past, alkylation of the trans-dithiolatoruthenium complex $\left[\mathrm{Ru}\left(\mathrm{PPh}_{3}\right)_{2} \mathrm{dttd}\right]$ by $\mathrm{CH}_{2} \mathrm{Cl}_{2}$, yielding the chloromethyl thioether complexes $\left[\mathrm{Ru}(\mathrm{X})\left(\mathrm{PPh}_{3}\right) \mathrm{dttd}\right.$ $\mathrm{CH}_{2} \mathrm{Cl}$ ], where $X$ is azide or cyanide, has been reported. ${ }^{17}$ Alkylation across cis thiolates, yielding a methylene-bridged dithioether Ru complex, has been reported lately. ${ }^{15}$ Similar additions of $\mathrm{CH}_{2} \mathrm{Br}_{2}$ across adjacent sulfido sulfurs have been previously reported. ${ }^{18}$

Concluding Remarks. Reactions of two ruthenium acetylide complexes with $\mathrm{EtO}_{2} \mathrm{CNCS}$ have yielded a series of addition products. Cycloaddition of the $\mathrm{C}=\mathrm{S}$ bond of $\mathrm{EtO}_{2} \mathrm{CNCS}$ with the acetylide ligand gives the four-membered-ring 2-iminothiete product. Opening of the 2-iminothiete ring causes slow isomerization of complex $\mathbf{2 a}$ to $\mathbf{3 a}$, which undergoes alkylation by $\mathrm{CH}_{2-}$ $\mathrm{Cl}_{2}$ at the thione sulfur atom to yield the new sixmembered-ring oxazine complex 5a. Alkylation of complex $3 \mathbf{a}$ by the chloromethyl group of $\mathbf{5 a}$ followed by loss of $\mathrm{EtCl}$ affords the binuclear complex $\mathbf{6 a}$ with two heterocyclic six-membered-ring ligands bridged by a methylene group.

\section{Experimental Section}

General Procedures. All manipulations were performed under nitrogen using vacuum-line, drybox, and standard Schlenk techniques. $\mathrm{CH}_{2} \mathrm{Cl}_{2}$ was distilled from $\mathrm{CaH}_{2}$ and diethyl ether and THF from sodium benzophenone ketyl. All other solvents and reagents were of reagent grade and were used without further purification. NMR spectra were recorded on Bruker AC-200 and AM-300WB FT-NMR spectrometers at room temperature (unless stated otherwise) and are reported in units of $\delta$ with residual protons in the solvents as an initial

(16) (a) Thompson, M. C.; Busch, D. H. J . Am. Chem. Soc. 1964, 86, 3651-3656. (b) Constable, E. C. Metals and Ligand Reactivity: An Introduction to the Organic Chemistry of Metal Complexes, 2nd ed.; VCH: Weinheim, Germany, 1996. (c) Musie, G.; Reibenspies, J . H.; Darensbourg, M. Y. Inorg. Chem. 1998, 37, 302. (d) Grapperhaus, C. A.; Darensbourg, M. Y. Acc. Chem. Res. 1998, 31, 451. (e) Darensbourg, M. Y.; Tuntulani, T.; Reibenspies, J . H. Inorg. Chem. 1995, 34, 6287. (f) Lyon, E.J .; Musie, G.; Reibenspies, J . H.; Darensbourg, M. Y. Inorg Chem. 1998, 37, 6942

(17) (a) Sellmann, D.; Waeber, M.; Binder, H.; Boese, R. Z. Naturforsch., B: Chem. Sci. 1986, 41b, 1541. (b) $\mathrm{dttd}^{2-}=2,3 ; 8,9-$ dibenzo1,4,7,10-tetrathiadecane(2-)

(18) McKenna, M.; Wright, L. L.; Miller, D. J .; Tanner, L.; Haltiwanger, R. C.; DuBois, M. R. J . Am. Chem. Soc. 1983, 105, 5329. standard $\left(\mathrm{CDCl}_{3}, \delta\right.$ 7.24: acetone- $\mathrm{d}_{6}, \delta$ 2.04). The complexes $[\mathrm{M}] \mathrm{C} \equiv \mathrm{CPh}\left(\mathbf{l a},[\mathrm{M}]=[\mathrm{Ru}]=\mathrm{Cp}(\mathrm{dppe}) \mathrm{Ru} ; \mathbf{1 b},[\mathrm{M}]=\left[\mathrm{Ru}^{\prime}\right]=\right.$ $\mathrm{Cp}\left(\mathrm{PPh}_{3}\right)\left[\mathrm{P}(\mathrm{OMe})_{3}\right] \mathrm{Ru}$ ) were prepared by following the methods reported in the literature. ${ }^{19,8} \mathrm{FAB}$ mass spectra were recorded on a J EOL SX-102A spectrometer. Elemental analyses and X-ray diffraction studies were carried out at the Regional Center of Analytical Instrument located at the National Taiwan University.

Synthesis of $[\mathrm{Ru}] \mathrm{C}=\mathrm{C}(\mathrm{Ph}) \mathrm{C}\left(=\mathrm{NCO}{ }_{2} \mathrm{Et}\right) \mathrm{S}$ (2a). In a Schlenk flask charged with $\mathbf{1 a}(300.1 \mathrm{mg}, 0.451 \mathrm{mmol})$ was added $\mathrm{CHCl}_{3}(20 \mathrm{~mL})$, and then $\mathrm{EtO}_{2} \mathrm{CNCS}(56.0 \mu \mathrm{L}, 0.473$ $\mathrm{mmol}$ ) was injected by a microsyringe. The resulting solution was stirred at room temperature for $1 \mathrm{~h}$, and the color changed from bright yellow to orange. The solvent was reduced to 1 $\mathrm{mL}$ under vacuum, and $30 \mathrm{~mL}$ of $\mathrm{n}$-pentane was added to cause precipitation of an orange powder. After filtration, the pre cipitate was washed with $10 \mathrm{~mL}$ of n-pentane and dried under vacuum to give the product $2 \mathrm{a}(331.2 \mathrm{mg}, 0.416 \mathrm{mmol}, 92 \%$ yield). Spectroscopic data of $\mathbf{2 a}$ are as follows. ${ }^{1} \mathrm{H}$ NMR $\left(\mathrm{CDCl}_{3}\right): \delta 7.79-6.69(\mathrm{~m}, 25 \mathrm{H}, \mathrm{Ph}), 4.60(\mathrm{~s}, 5 \mathrm{H}, \mathrm{Cp}), 4.07(\mathrm{q}$, $2 \mathrm{H}, \mathrm{CH}_{2}$, J $\left.\mathrm{H}-\mathrm{H}=7.10 \mathrm{~Hz}\right), 2.60,2.15\left(\mathrm{~m}, 2 \mathrm{H}, \mathrm{PCH}_{2}\right), 1.19(\mathrm{t}$, $\left.3 \mathrm{H}, \mathrm{CH}_{3}, \mathrm{~J}_{\mathrm{H}-\mathrm{H}}=7.10 \mathrm{~Hz}\right) .{ }^{31} \mathrm{P} \mathrm{NMR}\left(\mathrm{CDCl}_{3}\right): \delta 96.72 .{ }^{13} \mathrm{C} \mathrm{NMR}$ $\left(\mathrm{CDCl}_{3}\right): \delta 162.0(\mathrm{CO}), 143.4(\mathrm{SCN}), 136.4-126.1\left(\mathrm{~m}, \mathrm{Ph}, \mathrm{C}_{\alpha}\right.$ and $\left.\mathrm{C}_{\beta}\right), 87.9(\mathrm{Cp}), 61.3\left(\mathrm{OCH}_{2}\right), 30.4\left(\mathrm{t}, \mathrm{PCH}_{2}, \mathrm{~J}_{\mathrm{C}-\mathrm{p}}=22.4\right.$ $\mathrm{Hz}), 14.0\left(\mathrm{CH}_{3}\right)$. MS (FAB, m/z): $798.2\left(\mathrm{M}^{+}+1\right), 666.2\left(\mathrm{M}^{+}-\right.$ $\left.\mathrm{EtO}_{2} \mathrm{CNCS}\right), 565.5\left(\mathrm{M}^{+}-\mathrm{EtO}_{2} \mathrm{CNCS}-\mathrm{C} \equiv \mathrm{CPh}\right)$. Anal. Calcd for $\mathrm{C}_{43} \mathrm{H}_{39} \mathrm{O}_{2} \mathrm{NSP}_{2} \mathrm{Ru}$ : C, 64.81; $\mathrm{H}, 4.93 ; \mathrm{N}, 1.76$. Found: $\mathrm{C}$, 65.12; H, 5.09; N, 1.63 .

Synthesis of $\left[\mathrm{Ru}^{\prime}\right] \mathrm{C}=\mathrm{C}(\mathrm{Ph}) \mathrm{C}\left(=\mathrm{NCO}_{2} \mathrm{Et}\right) \mathrm{S}$ (2b). In a Schlenk flask charged with $\mathbf{l a}(200.1 \mathrm{mg}, 0.306 \mathrm{mmol})$ was added $\mathrm{CHCl}_{3}(20 \mathrm{~mL})$, and $\mathrm{EtO}_{2} \mathrm{CNCS}(39.6 \mu \mathrm{L}, 0.336 \mathrm{mmol})$ was injected by a microsyringe. The resulting solution was stirred at room temperature for $1 \mathrm{~h}$, and the col or changed from bright yellow to orange. The solvent was reduced to 1 $\mathrm{mL}$ under vacuum, and $20 \mathrm{~mL}$ of hexane was added to cause precipitation of an orange powder. After filtration, the pre cipitate was washed with $10 \mathrm{~mL}$ of hexane and then dried under vacuum to give the product $\mathbf{2 b}$ (199.4 $\mathrm{mg}, 0.254 \mathrm{mmol}$, $83 \%$ yield). Spectroscopic data of $\mathbf{2} \mathbf{b}$ are as follows. ${ }^{1} \mathrm{H}$ NMR (acetone $\mathrm{d}_{6}$ ): $\delta 7.85-6.90(\mathrm{~m}, 2 \mathrm{H}, \mathrm{Ph}), 4.21(\mathrm{~s}, 5 \mathrm{H}, \mathrm{Cp}), 4.13$ (q, $\left.2 \mathrm{H}, \mathrm{CH}_{2}, \mathrm{~J}_{\mathrm{H}-\mathrm{H}}=7.14 \mathrm{~Hz}\right), 3.42\left(\mathrm{~d}, 9 \mathrm{H}, \mathrm{P}(\mathrm{OMe})_{3}, \mathrm{~J}_{\mathrm{H}-\mathrm{P}}=\right.$ $11.12 \mathrm{~Hz}), 1.16\left(\mathrm{t}, 3 \mathrm{H}, \mathrm{CH}_{3}, \mathrm{~J} \mathrm{H}-\mathrm{H}=7.14 \mathrm{~Hz}\right)$. ${ }^{31} \mathrm{P} N M R$ $\left(\mathrm{CDCl}_{3}\right): \delta 152.72,56.92(2 \mathrm{~d}, \mathrm{~J}-\mathrm{p}=67.13 \mathrm{~Hz}) \cdot{ }^{13} \mathrm{C} \mathrm{NMR}$ $\left(\mathrm{CDCl}_{3}\right): \delta 167.4,161.8(\mathrm{CO}$ and $\mathrm{SCN}), 138.4-126.5(\mathrm{~m}, \mathrm{Ph}$, $\mathrm{C}_{\alpha}$ and $\left.\mathrm{C}_{\beta}\right), 86.2(\mathrm{Cp}), 61.6\left(\mathrm{OCH}_{2}\right), 52.8\left(\mathrm{~d}, \mathrm{~J}_{\mathrm{C}-\mathrm{P}}=7.5 \mathrm{~Hz}\right.$, $\left.\mathrm{P}(\mathrm{OMe})_{3}\right), 14.7\left(\mathrm{CH}_{3}\right)$. MS (FAB, m/z): $786.1\left(\mathrm{M}^{+}+1\right), 553.1$ $\left(\mathrm{M}^{+}-\mathrm{EtO}_{2} \mathrm{CNCS}-\mathrm{C} \equiv \mathrm{CPh}\right), 429.0\left[\mathrm{M}^{+}-\mathrm{EtO}_{2} \mathrm{CNCS}-\mathrm{C} \equiv\right.$ $\mathrm{CPh}-\mathrm{P}(\mathrm{OMe})_{3}$ ]. Anal. Calcd for $\mathrm{C}_{38} \mathrm{H}_{39} \mathrm{O}_{5} \mathrm{NSP}_{2} \mathrm{Ru}$ : C, 58.15; $H, 5.01 ; N, 1.78$. Found: C, 58.38; $H, 5.24 ; N, 1.75$.

Synthesis of $[R u] \mathbf{C}=\mathbf{C}(\mathbf{P h}) \mathbf{C}(=\mathbf{S}) \mathbf{N}=\mathbf{C}(\mathrm{OEt}) \mathbf{O}$ (3a). In a Schlenk flask charged with 1a (200.3 mg, $0.301 \mathrm{mmol})$ was added $\mathrm{CHCl}_{3}(20 \mathrm{~mL})$, and then $\mathrm{EtO}_{2} \mathrm{CNCS}(37.3 \mu \mathrm{L}, 0.316$ $\mathrm{mmol}$ ) was injected by a microsyringe. The resulting solution was stirred at room temperature for 1 day. The solvent was reduced to $1 \mathrm{~mL}$ under vacuum, and $30 \mathrm{~mL}$ of $\mathrm{n}$-pentane was added to cause precipitation of an orange-yellow powder. After filtration, the precipitate was washed with $10 \mathrm{~mL}$ of $\mathrm{n}$-pentane and dried under vacuum to give a mixture of $\mathbf{2 a}$ and $\mathbf{3 a}$ (211.0 $\mathrm{mg}, 88 \%$ total yiel d) in a ratio of ca. 1:3. Spectroscopic data of 3a are as follows. ${ }^{1} \mathrm{H}$ NMR $\left(\mathrm{CDCl}_{3}\right): \delta 7.79-6.95(\mathrm{~m}, 25 \mathrm{H}, \mathrm{Ph})$, $3.88(\mathrm{~s}, 5 \mathrm{H}, \mathrm{Cp}), 3.79\left(\mathrm{q}, 2 \mathrm{H}, \mathrm{CH}_{2}, \mathrm{~J}_{\mathrm{H}-\mathrm{H}}=7.05 \mathrm{~Hz}\right), 3.10,2.65$ $\left(\mathrm{m}, 2 \mathrm{H}, \mathrm{PCH}_{2}\right), 0.88\left(\mathrm{t}, 3 \mathrm{H}, \mathrm{CH}_{3}, \mathrm{~J} \mathrm{H}-\mathrm{H}=7.05 \mathrm{~Hz}\right)$. ${ }^{31} \mathrm{P} \mathrm{NMR}$ $\left(\mathrm{CDCl}_{3}\right): \delta 96.03 .{ }^{13} \mathrm{C} \mathrm{NMR}\left(\mathrm{CDCl}_{3}\right): \delta 216.6\left(\mathrm{t}, \mathrm{C}_{\alpha}, \mathrm{J} \mathrm{c}-\mathrm{p}=\right.$ $13.6 \mathrm{~Hz}$ ), 194.6 (CS), 155.5 (CO), 143.4, 134.0-126.6 (m, Ph,

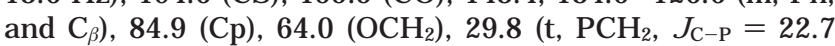

(19) Synthesis of acetylide: (a) Bruce, M. I. Aust. J . Chem. 1977, 30, 1602. (b) Oshima, N.; Suzuki, H.; Moro-oka, Y. Chem. Lett. 1984, 1161. 
$\mathrm{Hz}), 14.0\left(\mathrm{CH}_{3}\right) . \mathrm{MS}(\mathrm{FAB}, \mathrm{m} / \mathrm{z}): 797.0\left(\mathrm{M}^{+}\right), 565.0\left(\mathrm{M}^{+}-\mathrm{EtO}_{2^{-}}\right.$ $\mathrm{CNCS}-\mathrm{C} \equiv \mathrm{CPh}$ ).

Observation of the Intermediate $\{[R u] C=C(P h) C$ (SCH ${ }_{2} \mathrm{CI}$ )NC(OEt)O [CI] (4a). In a Schlenk flask charged with a mixture of $\mathbf{2 a}$ and $\mathbf{3 a}$ in a ratio of ca. $\mathbf{1 : 3}$ was added $\mathrm{CH}_{2} \mathrm{Cl}_{2}(20 \mathrm{~mL})$. The reaction was monitored by ${ }^{31} \mathrm{P} N M R$ spectroscopy. The resulting solution was stirred at room temperature for hours, and the additional intermediate $\{[R u]-$

$\left.\mathrm{C}=\mathrm{C}(\mathrm{Ph}) \mathrm{C}\left(\mathrm{SCH}_{2} \mathrm{Cl}\right) \mathrm{NC}(\mathrm{OEt}) \mathrm{O}\right\}[\mathrm{Cl}]$ (4a) was observed. We failed to isolate $\mathbf{4 a}$. Spectroscopic data of $\mathbf{4 a}$ are as follows. ${ }^{1} \mathrm{H}$ NMR $\left(\mathrm{CDCl}_{3}\right): \delta 4.70\left(\mathrm{CH}_{2} \mathrm{Cl}\right), 4.12(\mathrm{~s}, 5 \mathrm{H}, \mathrm{Cp}), 4.06(\mathrm{q}, 2 \mathrm{H}$, $\left.\mathrm{CH}_{2}, \mathrm{~J} \mathrm{H}_{-\mathrm{H}}=7.02 \mathrm{~Hz}\right), 1.04\left(\mathrm{t}, 3 \mathrm{H}, \mathrm{CH}_{3}, \mathrm{~J} \mathrm{H}-\mathrm{H}=7.02 \mathrm{~Hz}\right) .{ }^{31} \mathrm{P}$ NMR $\left(\mathrm{CDCl}_{3}\right): \delta$ 92.71. MS (m/z, Ru, $\left.{ }^{102} \mathrm{Cl}^{35}\right): 846.0\left(\mathrm{M}^{+}-\mathrm{Cl}\right)$, $593.0\left(\mathrm{M}^{+}-\mathrm{Cl}+\mathrm{CO}-\right.$ organic ligand $), 565.0\left(\mathrm{M}^{+}-\mathrm{Cl}-\right.$ organic ligand).

Synthesis of $[\mathbf{R u}] \mathbf{C}=\mathbf{C}(\mathbf{P h}) \mathbf{C}\left(\mathbf{S C H}_{2} \mathbf{C l}\right) \mathbf{N C}(=\mathbf{0}) \mathbf{O}(5 \mathrm{a}) . \mathrm{In}$ a Schlenk flask charged with $2 \mathbf{2 a}(200.1 \mathrm{mg}, 0.251 \mathrm{mmol})$ was added $\mathrm{CH}_{2} \mathrm{Cl}_{2}(50 \mathrm{~mL})$. The resulting solution was stirred at room temperature for 4 days, and the color changed from orange-yellow to yellow. The solvent was removed under vacuum, and the yellow precipitate was washed with $2 \times 10$ $\mathrm{mL}$ of hexane and dried under vacuum to give the product $\mathbf{5 a}$ (178.7 mg, $0.219 \mathrm{mmol}, 87 \%$ yield). Spectroscopic data of $\mathbf{5 a}$ are as follows. ${ }^{1} \mathrm{H}$ NMR $\left(\mathrm{CDCl}_{3}\right): \delta 7.70-7.12(\mathrm{~m}, 25 \mathrm{H}, \mathrm{Ph})$, 4.86 (s, 2H, $\left.\mathrm{CH}_{2}\right), 3.95$ (s, 5H, Cp), 3.42, $2.54\left(\mathrm{~m}, 4 \mathrm{H}, \mathrm{PCH}_{2^{-}}\right.$ $\left.\mathrm{CH}_{2} \mathrm{P}\right) .{ }^{31} \mathrm{P} \mathrm{NMR}\left(\mathrm{CDCl}_{3}\right): \delta 98.65 .{ }^{13} \mathrm{C} \mathrm{NMR}\left(\mathrm{CDCl}_{3}\right): \delta 233.6$ $\left(\mathrm{t}, \mathrm{C}_{\alpha}, \mathrm{J}_{\mathrm{C}-\mathrm{p}}=14.5 \mathrm{~Hz}\right), 152.1$ (CO), 139.5 (NCS), 133.2-128.1 $\left(\mathrm{m}, \mathrm{Ph}\right.$ and $\left.\mathrm{C}_{\beta}\right), 84.4(\mathrm{Cp}), 43.1\left(\mathrm{CH}_{2}\right), 29.7\left(\mathrm{t}, \mathrm{PCH}_{2}, \mathrm{~J} \mathrm{c}-\mathrm{P}=\right.$ $22.4 \mathrm{~Hz})$. MS (FAB, $\mathrm{m} / \mathrm{z}): 818.1\left(\mathrm{M}^{+}+1\right), 593.1\left(\mathrm{M}^{+}+\mathrm{CO}-\right.$ organic ligand), 565.1 ( $\mathrm{M}^{+}-$organic ligand). Anal. Calcd for $\mathrm{C}_{42} \mathrm{H}_{36} \mathrm{O}_{2} \mathrm{NSClP}_{2} \mathrm{Ru}: \mathrm{C}, 61.72 ; \mathrm{H}, 4.44 ; \mathrm{N}, 1.71$. Found: C, 62.07; H, 4.72; N, 1.63 .

Synthesis of $[[R u] C=C(P h) C(S-) N C(=0)]_{2} \mathrm{CH}_{2}(6 a)$. In a Schlenk flask charged with $2 \mathbf{2 a}(200.1 \mathrm{mg}, 0.251 \mathrm{mmol})$ was added $\mathrm{CH}_{2} \mathrm{Cl}_{2}(10 \mathrm{~mL})$. The resulting solution was stirred at room temperature for 4 days to give a mixture of $\mathbf{5 a}$ and $\mathbf{6 a}$ in a ratio of ca. 3:2. Complexes $5 \mathbf{a}$ and $\mathbf{6 a}$ were separated by their different solubilities in acetone. Thus, after the solvent was removed under vacuum, $30 \mathrm{~mL}$ of cold acetone was added. Complex $\mathbf{6 a}$ preci pitated out from the acetone solution. After filtration, the yellow precipitate was washed with $2 \times 5 \mathrm{~mL}$ of cold acetone and then dried under vacuum to give the product 6a (64.2 mg, $0.042 \mathrm{mmol}$, 33\% yield). Spectroscopic data of $6 \mathbf{a}$ are as follows. ${ }^{1} \mathrm{H}$ NMR $\left(\mathrm{CDCl}_{3}\right): \delta$ 7.63-7.02 (m, $50 \mathrm{H}, \mathrm{Ph}), 4.20\left(\mathrm{~s}, 2 \mathrm{H}, \mathrm{CH}_{2}\right), 3.93$ (s, 10H, Cp), 3.43, $2.55(\mathrm{~m}$, $\left.4 \mathrm{H}, \mathrm{PCH}_{2}\right) .{ }^{31} \mathrm{P} \mathrm{NMR}\left(\mathrm{CDCl}_{3}\right): \delta 98.84 .{ }^{13} \mathrm{C} \mathrm{NMR}\left(\mathrm{CDCl}_{3}\right): \delta$ 154.2 (CO), 143.6 (NCS), 133.5-127.6 (m, Ph and $\mathrm{C}_{\beta}$ ), 84.4 (Cp), $30.9\left(\mathrm{CH}_{2}\right), 29.7\left(\mathrm{t}, \mathrm{PCH}_{2}, \mathrm{~J}_{\mathrm{C}-\mathrm{P}}=22.4 \mathrm{~Hz}\right) . \mathrm{MS}(\mathrm{FAB}$, $\mathrm{m} / \mathrm{z}): 1551.0\left(\mathrm{M}^{+}+1\right), 593.0\left(\mathrm{M}^{+}+\mathrm{CO}\right.$ - organic ligand), 565.1 ( $\mathrm{M}^{+}-$organic ligand). Anal. Calcd for $\mathrm{C}_{83} \mathrm{H}_{70} \mathrm{O}_{4} \mathrm{~N}_{2} \mathrm{~S}_{2} \mathrm{P}_{4} \mathrm{Ru}_{2}$ : C, 64.33; H, 4.55; N, 1.81. Found: C, 64.11; H, 4.78; N, 1.68.

X-ray Analysis of $\mathbf{2 b}, \mathbf{3 a}, \mathbf{5 a}$, and $\mathbf{6 a}$. Single crystals suitable for $\mathrm{X}$-ray diffraction studies were grown as mentioned above. The chosen single crystal was glued to a glass fiber and mounted on a SMART CCD diffractometer. The data were collected with use of $3 \mathrm{~kW}$ sealed-tube molybdenum $\mathrm{K} \alpha$ radiation $(\lambda=0.7107 \AA$ ). The exposure time was $5 \mathrm{~s}$ per frame. ${ }^{20}$ The intensity was intergrated, and absorption corrections were applied by using SADABS. ${ }^{21}$ Data were processed and refined by the SHE LXTL ${ }^{22}$ program. Hydrogen atoms were placed geometrically using the riding model with thermal parameters set to 1.2 times those for the atoms to which the hydrogen is attached and 1.5 times those for the methyl hydrogens. Crystal data for $\mathbf{2} \mathbf{b}, \mathbf{3} \mathbf{a}, \mathbf{5} \mathbf{a}$, and $\mathbf{6} \mathbf{a}$ are listed in Table 1. Final values of all refined atomic positional parameters (with esd's) and tables of thermal parameters are given in the Supporting Information.

Acknowledgment. We are grateful for support of this work by the National Science Council, Taiwan, Republic of China.

Supporting Information Available: Details about the X-ray crystal structures, including diagrams and tables of crystal data and structure refinement details, atomic coordinates, bond lengths and angles, and anisotropic displacement parameters for $\mathbf{2 b}, \mathbf{3 a}, \mathbf{5 a}$, and $\mathbf{6 a}$. This material is available free of charge via the Internet at http://pubs.acs.org.

\section{OM030341W}

(20) X-ray: SAINT (Siemens Area Detector Intergration) program; Siemens Analytical X-ray: Madison, WI, 1995.

(21) The SADABS program is based on the method of Blessing; see: Blessing, R. H. Acta Crystallogr., Sect. A 1995, 51, 33.

(22) SHELXTL: Structure Analysis Program, version 5.04; Siemens Industrial Automation, Inc., Madison, WI, 1995. 